Original Article

\title{
Prevalence of gastrointestinal parasitic infection in cows and buffaloes in Lower Dir, Khyber Pakhtunkhwa, Pakistan
}

\author{
Prevalência de infecções parasitárias gastrointestinais em vacas e búfalos em Lower \\ Dir, Khyber Pakhtunkhwa, Paquistão
}

\author{
T. Khan ${ }^{\mathrm{a}, \mathrm{b}}$, W. Khan ${ }^{\mathrm{b} *}$ (1), Roohullah Iqbala,b, A. Maqboola, Y.A..J. Fadladdinn, T. Sabtain ${ }^{\mathrm{d}}$ \\ aVirtual University of Pakistan, Faculty of Science and Technology, Department of Biology, Islamabad, Pakistan \\ bUniversity of Malakand, Department of Zoology, Laboratory of Parasitology, Lower Dir, Pakistan \\ 'Department of Biological Sciences, Faculty of Sciences, King Abdul Aziz University Jeddah, Kingdom of Saudi Arabia \\ dUniversity of Agriculture, Department of Zoology, Wild Life and Fisheries, Faisalabad, Pakistan
}

\begin{abstract}
Gastrointestinal (GI) Parasitic infection is a hot issue for cattle management. There is variation of GI parasites effects in sex, age of cattle, drinking water condition, nutrition, and severity of infection. Studies on prevalence of GI parasites among cattle population in Dir Lower are lacking. A total of 40 farms were selected randomly in six tehsil namely Tehsil Adenzai, Tehsil Timergara, Tehsil Balambat, Tehsil Munda ,Tehsil Lalqala, Tehsil Khall. Freshly cattle fecal samples were collected randomly from the selected farms during March 2018 till December 2018. Out of 314 buffaloes and cattle examined 58.59\% (184/314) were positive for eggs, cyst/oocyst of one or more species of GI Parasites. The prevalence of parasitic infection was higher in Buffaloes 63.55\% (75/118) as compared to Cow $55.61 \%$ (109/196) but the difference was not significant (p>0.05) Entamoeba,spp, Moniezia spp, Haemonchus spp and Coccidian spp were found in this study. The non-treated animals indicated the highest percentage of infection in cow 57.71\% (101/175) and buffalo 68.13\% (62/91).GI parasite prevalence in female animal were higher female cow $62.58 \%$ (87/139) and female buffalo $77.33 \%$ (58/75) as compared to male. But the difference is non-significant ( $p>0.05$ ) Yearling calves had the lower rate of GI parasitic infection than adults. Future investigations are necessary to evaluate the economic loss due to GI parasites in cattle's.
\end{abstract}

Keywords: cattle, buffalo, prevalence, gastrointestinal parasites, Entamoeba spp.

\begin{abstract}
Resumo
A infecção gastrointestinal (GI) parasitária é um assunto importante para o manejo do gado. Existem variações nos efeitos dos parasitas GI quanto a sexo, idade do gado, condição da água potável, nutrição e gravidade da infecção. Faltam estudos sobre a prevalência de parasitas GI entre a população de gado em Lower Dir. Um total de 40 fazendas foi selecionado aleatoriamente em seis tehsil, nomeadamente Tehsil Adenzai, Tehsil Timergara, Tehsil Balambat, Tehsil Munda, Tehsil Lalqala, Tehsil Khall. Amostras fecais de gado fresco foram coletadas aleatoriamente das fazendas selecionadas de março de 2018 até dezembro de 2018. Dos 314 búfalos e bovinos examinados, 58,59\% (184/314) foram positivos para ovos, cisto/oocisto de uma ou mais espécies de parasitas GI. A prevalência de infecção parasitária foi maior em Buffaloes 63,55\% (75/118) em comparação com vaca 55,61\% (109/196), mas a diferença não foi significativa ( $>$ > 0,05). Entamoeba spp, Moniezia spp, Haemonchus spp e Coccidian spp foram encontrados neste estudo. Os animais não tratados indicaram a maior porcentagem de infecção em vacas 57,71\% (101/175) e búfalos 68,13\% (62/91). A prevalência do parasita GI em fêmeas foi maior em vacas fêmeas $62,58 \%(87 / 139)$ e búfalas $77,33 \%$ (58/75) em comparação ao masculino. Mas a diferença não é significativa ( $p>0,05)$. A modelagem linear geral mostrou que o tratamento do animal estava significativamente relacionado com a prevalência de parasitas GI. Bezerros de um ano tiveram a maior taxa de infecção parasitária gastrointestinal. Futuras investigações são necessárias para avaliar a perda econômica devido aos parasitas GI em bovinos.
\end{abstract}

Palavras-chave: bovinos, búfalos, prevalência, parasitas gastrointestinais, Entamoeba spp.

\section{Introduction}

The agriculture sector is has a key role in developing the economy of a country. Pakistan is considered an agricultural country, but with repaid decline in the performance of agriculture sector due to various reasons like social political condition, climate and environmental issues. Today it is considered the second largest sector in economy of

*e-mail: walikhan.pk@gmail.com

Received: August 24, 2020 - Accepted: January 5, 2021 
Pakistan. About 20 percent GDP and 46 percent of labor are engaged in this sector to earn live hood. About 62 percent of people of Pakistan live in rural areas who are directly or indirectly linked with agriculture (Raza et al., 2012).

The role of parasitism is very much significant in most of the agro-ecological regions and a major threat to worldwide livestock economy (Vercruysse and Claerebout, 2001). Helminths infection are considered one of the chief restraint to the production of livestock all over the subtropics and tropic region (Githiori et al., 2004). It reduces the efficiency and productivity cause of high economic losses (Sykes, 1994) and increase mortality which effect the income of farming communities.

An efficient, effective and good strategy is necessary for fruitful implementation and formulation of gastrointestinal parasitic infection control. A periodic surveillance is required for the frequency of gastrointestinal parasitic infections in a particular environment and their association to risk factors which effect the transmission of parasites. From various parts in the world about 0.72 to $84.1 \%$ gastrointestinal parasites prevalence has been reported (Bundy et al., 1983; Khan et al., 2010).

Pastoral grazing system is the main cause of gastrointestinal parasitic infections. Many Gastrointestinal parasitic species have developed resistance to antigastrointestinal parasitic drugs (Waller, 1994; Min et al., 2005). Due to Gastrointestinal parasitic infection the productivity of animals has reduced and affected the animal performance also (Waller, 1999). Lower growth rate, impaired tissue deposition, productivity and feed intake depress is caused by subclinical gastrointestinal parasitic infections (Sykes, 1994). In young animals mortality may exceed 40\% while losses in weight occur 6-13 kilogram per year in per animal (Waller, 1999; Hawkins, 1993).

Buffaloes and cows are not only the sources of animal proteins, but other products which are made from their fetch are very much important for the use of man. Trematode parasites cause secondary infections as well as weakness, watery diarrhea, weight loss, reduced product quality and decrease in milk production also (Solusby, 1982; Gupta et al., 1978). Enormous economic losses occur due to gastrointestinal parasitic infections. Abdominal vermin are parasites which can damage the gastrointestinal walls of human as well as other animals (Loukopoulos et al., 2007). The gastrointestinal parasites are majour health problems to the health of small ruminants in Upper Dir district, Pakistan (Ruhoollah et al., 2023). Similarly gastro-intestinal parasites are a serous problem in cattle and buffaloes in the Loer Dir, Pakistan (Khan et al., 2021).

They live through all the physique, but favour the abdominal wall (Coop and Holmes, 1996). Protozoans have the ability that can directly infect if they out from the abdomen into the environment hence the helminthic needed the period of maturation in the soil while other have some extant of intermediate host for the (Arcari et al., 2000). The most constructive places for abdominal parasites are the small part of stomach, ileum, cecum and big intestine (Cuomo et al., 2009). For the endure or replicate in the intestinal tract the vermin have to familiarise with incessant physical changes comparative to the nourishing homes of the host (Cuomo et al., 2009). Large ruminants are pretentious with dissimilar types of vermin (Coop and Kyriazakis, 1999), while in some case are deadly because of the parasites types.

Because of unhygienic environment, improper care, close interaction with septic animals and extreme climate sheep and goat become infected with large variability of gastrointestinal parasites (Gadahi et al., 2009.). Most of ruminants badly are affected by helminthiasis, which cause biochemical and hematological disturbance, anorexia, poor reproductive performance, weight loss and decreased animal confrontation to diseases that can lead to death or even become the cause of lots of mortality among the ruminant and lead to a great economic loss (Ngategize et al., 1993). It is reported that reduction occurred in farmer profit up to $16 \%$ and decrease in weight up to $50 \%$ is because of gastrointestinal parasitic infections. The current study was conducted to investigate the prevalence of gastrointestinal parasitic infection as to find out which parasites might be harboured by the large ruminants in Lower Dir district, Pakistan.

\section{Methodology}

\subsection{Study Area}

This study was conducted at District Dir lower Khyber PukhtunKhwa, Pakistan. The district lies in the northern highlands of KP at a latitude 34.35 , longitude 71.85 and altitude of 823 . The average annual temperature is $16^{\circ} \mathrm{C}$ and average annual rainfall is $1186 \mathrm{~mm}$ recorded. The relative humidity varies from 70 to $81 \%$ in rainy season and in dry season from 40 to $50 \%$ humidity is recorded.

\subsection{Study Population}

The study population consisted of all buffalos and cows in the study area.

\subsection{Sample collection and examination procedures}

\subsubsection{Collection}

Fecal samples were collected directly from the rectum of buffalos and cows randomly, using gloved fingers, put in clean sampling plastic bottles containing $10 \%$ formalin and giving sampling number. A questionnaire was also designed which included the following parameters: animal category, date, gender, area, age, season, grazing system, health status, condition of farm/household, treatment, socio-economic status of the farmer and source of drinking water. Samples were brought to the Laboratory of Parasitology in the Department of Zoology, University of Malakand for further analysis.

\subsubsection{Laboratory tools}

Normal saline $(0.85 \%)$, formalin, sugar, cotton, refrigerator, cover slip, centrifuge machine, slides, beaker, cello tape, glass rod, stick, measuring cylinder, needle, 
volumetric flask, gloves, Electronic weigh machine, mask, tea strainer, microscope, questioner, Pasteur pipette, rack, motor and pestle were the laboratory tool.

\subsection{Laboratory methods}

In the laboratory the samples were examined for the detection of gastrointestinal parasites eggs or cyst on the basis of morphology using the following methods.

\subsubsection{Direct smear methods (wet mount techniques)}

\subsubsection{Normal saline solution}

A solution of saline wet mount was made in which a 2 gram of faces were mixed within drop of saline upon a glass slide. Microscope was used for smear examination.

\subsubsection{Concentration techniques}

\subsubsection{Floatation and centrifugation}

This procedure is very popular and widely used for spotting eggs of nematodes and cestodes. As their eggs are lighter and small, they can float in the flotation liquid. Almost $3 \mathrm{gm}$ of stool sample was taken in a beaker and $42 \mathrm{ml}$ of water was added with the help of motor and pestle, sample was grinded lightly and clarified with a tea filter.

The samples which were filtered and poured into plastic tube of $15 \mathrm{ml}$ and were centrifuged at $1000 \mathrm{rpm}$ for 5 minutes. The plastic tube was taken out from the centrifuge and with the help of pipette the upper part of water was poured. Then again the tube was filled with $\mathrm{NaCl}$ solution and centrifuged at $1000 \mathrm{rpm}$ for 5-7 minutes. $\mathrm{NaCl}$ solution was added so that the tube may filled to the tip of the tube. Cover slip was put on top of the tube, so that the Sedum chloride trace the cover slip for few minutes and after few minutes cover slip will be put on a slide and was examined at 10X (Khan et al., 2018).

\subsubsection{Sedimentation technique}

This procedure is mostly used for spotting trematodes eggs because the trematodes eggs are bit denser than the other eggs .Havier egg settle down in bottom of test tube when its was centrifuged with sodium chloride solution.
With the help of pipette, a drop of deposited material was took on the slide. On it, a drop sodium chloride $(\mathrm{NaCl})$ was added and examined under a microscope at 4Xand 10X (Solusby, 1982).

\subsection{Statistical analysis}

Data was analyzed by used of Graph Pad version 5. Comparative prevalence of various gastrointestinal (GI) parasites group or species was calculated by following formula.

Prevalence $(\%)=($ Number of positive samples $/$ Total number of samples examined) $\mathrm{x} 100$

\section{Results}

The overall prevalence of GI parasites of study area was found $58.59 \%(184 / 314)$ with $55.61 \%(109 / 196)$ in cows and $63.55 \%(75 / 118)$ buffaloes with the occurrence of Entamoeba spp17.43\% (19/109), Moniezia spp 24.77\% (27/109), Haemunchus spp 40.36\% (44/109) and Coccidia spp $17.43 \%$ (19/109) in cows while the prevalence of Entamoeba app 25.33\% (19/75), Moniezia spp 14.66\% (11/75), Haemunchus spp 53.33\% (40/75) and Coccidia spp 6.66\% (5/75) in buffalos were found. The relationship between the examined samples and positive samples was significant (Table 1).

Prevalence in male cows was 38\% (22/57) and female cows $62.58 \%(87 / 139)$ as well as, in male buffalo the occurrence was found $39.53 \%$ (17/43) while in female buffalo $77.33 \%$ (58/75). The relationship between the examined sample and the positive sample was significant (Table 2).

Prevalence in young cows was $53.65 \%(22 / 41)$ and adult cows $56.12 \%(87 / 155)$ as well as, in young buffalos the occurrence was found young buffalos $38.23 \%$ (13/34) while in adult buffalos $73.8 \%$ (62/84). The relationship between the sample examined and that of infected was significant (Table 3 ).

Prevalence in treated cows was $38.09 \%(8 / 21)$ and untreated cows $57.71 \%(101 / 175)$ as well as, in treated buffaloes the occurrence was found $48.14 \%$ (13/27) while in untreated buffaloes $68.13 \%$ (62/91) Table 4 .

Table 1. Overall prevalence of Intestinal parasites in cows and buffalos in Lower Dir, Pakistan.

\begin{tabular}{|c|c|c|c|c|c|}
\hline \multirow[b]{2}{*}{ Parasites } & \multicolumn{2}{|c|}{ Cows $(n=196)$} & \multicolumn{2}{|c|}{ Buffaloes ( $n=118$ ) } & \multirow[b]{2}{*}{ Overall (\%) } \\
\hline & $\begin{array}{l}\text { Positive } \\
\text { Samples }\end{array}$ & Infection (\%) & $\begin{array}{l}\text { Positive } \\
\text { Samples }\end{array}$ & Infection (\%) & \\
\hline Entamoeba spp & 19 & 17.43 & 19 & 25.33 & 20.65 \\
\hline Moniezia spp & 27 & 24.77 & 11 & 14.66 & 20.65 \\
\hline Haemunchus spp & 44 & 40.36 & 40 & 53.33 & 45.65 \\
\hline Coccidia spp & 19 & 17.43 & 5 & 6.66 & 13.04 \\
\hline Total & 109 & 55.61 & 75 & 63.55 & 58.59 \\
\hline P value & \multicolumn{2}{|c|}{0.04} & \multicolumn{2}{|c|}{0.02} & \\
\hline
\end{tabular}


Table 2. Gender wise prevalence of GI parasites in cows and buffalos in district Lower Dir Pakistan.

\begin{tabular}{ccccc}
\hline Animal Category & Variables & No. Examined (n) & Positive Samples (n) & Infection (\%) \\
\hline Cow & Male & 57 & 22 & 38 \\
& Female & 139 & 87 & 62.58 \\
Overall & Total & 196 & 109 & 55.61 \\
Buffalo & Male & 43 & 58 & 39.53 \\
& Female & 75 & 75 & 77.33 \\
Overall & Total & 118 & 184 & 63.55 \\
Overall Animals & Total Gender & 314 & 58.59 \\
\hline
\end{tabular}

Table 3. Age wise prevalence of Intestinal parasites in cows and buffalos in district Lower Dir Pakistan.

\begin{tabular}{ccccc}
\hline Animal Category & Age & No. Examined (n) & Positive Samples (n) & Infection (\%) \\
\hline Cow & Young (2years) & 41 & 22 & 53.65 \\
& Adult (5years) & 155 & 87 & 56.12 \\
Overall & Total & 196 & 109 & 55.61 \\
Buffalo & Young (2years) & 34 & 13 & 38.23 \\
& Adult (5years) & 84 & 75 & 73.8 \\
Overall & Total & 118 & 184 & 63.55 \\
Overall Animals & Total Gender & 314 & & 58.59 \\
\hline
\end{tabular}

Table 4. Treatment wise prevalence of GI parasites in cows and buffalos in District Lower Dir, Pakistan.

\begin{tabular}{ccccc}
\hline Animal Category & Variables & No. Examined (n) & Positive Samples (n) & Infection (\%) \\
\hline cows & treated & 21 & 8 & 38.09 \\
& untreated & 175 & 101 & 57.71 \\
Overall & total & 196 & 109 & 55.61 \\
buffaloes & treated & 27 & 13 & 48.14 \\
& untreated & 91 & 75 & 68.13 \\
Overall & total & 118 & 184 & 63.55 \\
Overall animals & total treatment & 314 & & 58.59 \\
\hline
\end{tabular}

\section{Discussion}

Cows and buffaloes play an important role in the economy of Pakistan in view of elevation of poverty, production of milk owl, leather, and meat. But the gastrointestinal parasites cause huge morbidity and mortality in these animals, affect the economic condition of the country. A handsome amount of money is also spent on the treatment of gastrointestinal parasites of these animals. The current study was conducted in district Lower Dir to find out the gastrointestinal parasites of Cows and buffalos because less attention has been paid to the screening of cows and buffalo parasites.

In present study the overall prevalence occurred $58.59 \%$ with cows $55.61 \%$ and buffalos $63.55 \%$.Our finding is nearly similar and in line with the result of (Raza et al.,2012 (51\%) and buffaloes (47\%) (Jittapalapong et al., 2011 ) cows 46.6\% Dula, 2018 cows $40 \%$ but our result are less from the finding of (Marskole et al., 2016 ) Baffaloes 73.33\% and Cows 75\% were found. It may be due to differences in environmental status of the study area and methodology.

High prevalence was observed in female cows $62.58 \%$ while more occurrence also in female buffaloes $77.33 \%$. in this regard our finding is nearly similar in line with the result of Dula, 2018 found 39.9\% in male cows and $41.6 \%$ prevalence found in female cows but our result are less from the finding of (Raza et al., 2007) which may be during samples collection it was observed that more peoples keep female cows and buffalos for their daily life requirement like milk, and other dairy products. It may be due sensitive immune system of females animals during pregnancy and hormonal differences.

Regarding age, adult cows were highly affected by GI parasites $56.12 \%$ while more occurrence where also occurred in adult buffaloes $73.8 \%$. Our finding is nearly 
similar and in line with the result of Dula, 2018 cows young $38.3 \%$ while adult cows $41.9 \%$ but our result are less from the finding of Marskole et al., 2016 adult cows $77.50 \%$ and Adult Buffaloes 75\% as compared to young which are $56 \%$ in cattle and $62.59 \%$ in young Buffalos. The increase in the prevalence of GI parasites with the age has also been reported by Qureshi and Tanveer (2009); Telila et al. (2014). On the contrary, Ahmed et al. (2017) stated that the younger animals are more susceptible than adult animals. The more occurrence in adult animals maybe due to the weakness of immune system, and regular exposure to infected animals and contact with infected other animals.

Prevalence in treated cows was $38.09 \%$ and untreated cows $57.71 \%$ as well as, in treated buffaloes the occurrence was found $48.14 \%$ while in untreated buffalo $68.13 \%$. Our finding is closely similar and in line with the result of Gunathilaka et al. (2018) cows untreated $46.67 \%$ and treated cows $15 \%$ and untreated Buffalos $48.56 \%$ and treated Buffalos $17.78 \%$, but our results are different from the finding of Githiori et al. (2004). The high occurrence in untreated cows and buffalos were noted as compared to treated animals .The high prevalence rates in untreated animals may be due to untreated and lacking the used of medicine, un awareness in farmers about the use of anti-helminthic drugs to control GI parasites in animals.

\section{Acknowledgements}

All owners of the animals selected farms and farmers are greatly acknowledged for their cooperation in this study.

\section{References}

AHMED, J., DUGUMA, A., REGASSA, D., BELINA, D. and JILO, R., 2017. Gastrointestinal nematode parasites of small ruminants and anthelmintics efficacy test in sheep of Haramaya district, eastern Ethiopia. Anim Vet Sci, vol. 5, no. 3, pp. 39-44. http:// dx.doi.org/10.11648/j.avs.20170503.11.

ARCARI, M., BAXENDINE, A. and BENNETT, C.E., 2000. Diagnosing medical parasites through coprological techniques. Mumbai: Diasys Ltd. 120 p.

BUNDY, D.A., ARÁMBULO III, P.V. and GREY, C.L., 1983. Fascioliasis in Jamaica: epidemiologic and economic aspects of a snailborne parasitic zoonosis. Bulletin of the Pan American Health Organization, vol. 17, no. 3, pp. 243-258. PMid:6652318.

COOP, R.L. and HOLMES, P.H., 1996. Nutrition and parasite interaction. International Journal for Parasitology, vol. 26, no. 8-9, pp. 951-962. http://dx.doi.org/10.1016/S0020-7519(96)80070-1. PMid:8923142.

COOP, R.L. and KYRIAZAKIS, I., 1999. Nutrition-parasite interaction. Veterinary Parasitology, vol. 84, no. 3-4, pp. 187-204. http:// dx.doi.org/10.1016/S0304-4017(99)00070-9. PMid:10456415.

CUOMO, M.J., NOEL, L.B. and WHITE, D.B., 2009. Diagnosing medical parasites: a public health officers guide to assisting laboratory and medical officers. Fort Belvoir: Air Education and Training Command Randolph AFB TX.

DULA, T.I., 2018. Prevalence and risk factors of gastrointestinal nematodes infections in small ruminants in Sayyo District, Kellem Wollega Zone; Ethiopia. Advances in Biological Research, vol. 12, no. 2, pp. 85-90.
GADAHI, J.A., ARSHED, M.J., ALI, Q., JAVAID, S.B. and SHAH, S.I., 2009. Prevalence of gastrointestinal parasites of sheep and goat in and around Rawalpindi and Islamabad, Pakistan. Veterinary World, vol. 2, no. 2, pp. 51.

GITHIORI, J.B., HÖGLUND, J., WALLER, P.J. and BAKER, R.L., 2004. Evaluation of anthelmintic properties of some plants used as livestock dewormers against Haemonchus contortus infections in sheep. Parasitology, vol. 129, no. 2, pp. 245-253. http://dx.doi. org/10.1017/S0031182004005566. PMid:15376783.

GUNATHILAKA, N., NIROSHANA, D., AMARASINGHE, D. and UDAYANGA, L., 2018. Prevalence of gastrointestinal parasitic infections and assessment of deworming program among cattle and buffaloes in Gampaha District, Sri Lanka. BioMed Research International, vol. 2018, pp. 3048373. http://dx.doi. org/10.1155/2018/3048373. PMid:30402469.

GUPTA, P.P., SINGH, B., MANDAL, P.C., GILL, B.S. and GREWAL, G.S., 1978. A postmortem study of mortality pattern in adult buffaloes in Punjab. The Indian Journal of Animal Sciences, vol. 48, pp. 669.

HAWKINS, J.A., 1993. Economic benefits of parasite control in cattle. Veterinary Parasitology, vol. 46, no. 1-4, pp. 159-173. http:// dx.doi.org/10.1016/0304-4017(93)90056-S. PMid:8484208.

JITTAPALAPONG, S., SANGWARANOND, A., NIMSUPHAN, B., INPANKAEW, T., PHASUK, C., PINYOPANUWAT, N., CHIMNOI, W., KENGRADOMKIJ, C., ARUNWIPAT, P. and ANAKEWITH, T., 2011. Prevalence of gastro-intestinal parasites of dairy cows in Thailand. Witthayasan Kasetsat Witthayasat, vol. 45, no. 1, pp. 40-45.

KHAN, M.N., SAJID, M.S., KHAN, M.K., IQBAL, Z. and HUSSAIN, A., 2010. Gastrointestinal helminthiasis: prevalence and associated determinants in domestic ruminants of district Toba Tek Singh, Punjab, Pakistan. Parasitology Research, vol. 107, no. 4, pp. 787-794. http://dx.doi.org/10.1007/s00436-010-1931-x. PMid:20532913.

KHAN, W., NOOR-UN, N. and NAWAZ, M.A., 2018. Incidence of tapeworm infection in human population of Swat, Pakistan: an occupation based study. Pakistan Journal of Zoology, vol. 50, no. 2, pp. 639.

KHAN, T., NASREEN, N., SHATER, A.F., KHAN, A., KAMAL, M., VINUEZA, R., LEON, R., ALHIMAIDI, A.R. and AL-JABR, O.A., 2021. Risk factor analysis for the prevalence of gastrointestinal parasites found in large ruminants in Lower Dir Khyber Pakhtunkhwa Pakistan. Saudi journal of biological sciences, vol. 28, no. 12, pp. 7022-7026.

LOUKOPOULOS, P., KOMNENOU, A., PAPADOPOULOS, E. and PSYCHAS, V., 2007. Lethal Ozolaimus megatyphlon infection in a green iguana (Iguana iguana rhinolopa). Journal of Zoo and Wildlife Medicine, vol. 38, no. 1, pp. 131-134. http://dx.doi. org/10.1638/2006-0018R.1. PMid:17469289.

MARSKOLE, P., VERMA, Y., DIXIT, A.K. and SWAMY, M., 2016. Prevalence and burden of gastrointestinal parasites in cattle and buffaloes in Jabalpur, India. Veterinary World, vol. 9, no. 11, pp. 1214-1217. http://dx.doi.org/10.14202/vetworld.2016.1214-1217. PMid:27956771.

MIN, B.R., HART, S.P., MILLER, D., TOMITA, G.M., LOETZ, E. and SAHLU, T., 2005. The effect of grazing forage containing condensed tannins on gastro-intestinal parasite infection and milk composition in Angora does. Veterinary Parasitology, vol. 130, no. 1-2, pp. 105-113. http://dx.doi.org/10.1016/j. vetpar.2005.03.011. PMid:15893077.

NGATEGIZE, P.K., BEKELE, T. and TILAHUN, G., 1993. Financial losses caused by ovine fasciolosis in the Ethiopian highlands. Tropical Animal Health and Production, vol. 25, no. 3, pp. 155-161. http:// dx.doi.org/10.1007/BF02236234. PMid:8236492. 
QURESHI, A.W. and TANVEER, A., 2009. Seroprevalence of fasciolosis in buffaloes and humans in some areas of Punjab, Pakistan. Pakistan Journal of Science, vol. 61, no. 2, pp. 91-96.

RAZA, M.A., BACHAYA, H.A., AKHTAR, M.S., ARSHAD, H.M., MURTAZA, S., AYAZ, M.M., NAJEEM, M. and BASIT, A., 2012. Point prevalence of gastrointestinal helminthiasis in buffaloes (Bubalus bubalis) at the vicinity of Jatoi, Punjab, Pakistan. Sci. Int., vol. 24, no. 4, pp. 465-469.

RAZA, M.A., IQBAL, Z., JABBAR, A. and YASEEN, M., 2007. Point prevalence of gastrointestinal helminthiasis in ruminants in southern Punjab, Pakistan. Journal of Helminthology, vol. 81, no. 3, pp. 323-328. http://dx.doi.org/10.1017/S0022149X07818554. PMid:17711599.

SOLUSBY, E.J.L. 1982. Helminths, arthropods and protozoa of domesticated animals. 7th ed. London: Bailliere Tindall.

SYKES, A.R., 1994. Parasitism and production in farm animals. Animal Science, vol. 59, no. 2, pp. 155-172. http://dx.doi.org/10.1017/ S0003356100007649.

TELILA, C., ABERA, B., LEMMA, D. and ETICHA, E., 2014. Prevalence of gastrointestinal parasitism of cattle in East Showa Zone, Oromia regional state, Central Ethiopia. Journal of Veterinary
Medicine and Animal Health, vol. 6, no. 2, pp. 54-62. http:// dx.doi.org/10.5897/JVMAH2013.0260.

RUHOOLLAH, KHAN, W., AL-JABR, O.A., KHAN, T., KHAN, A., ELGHAREEB, W.R., AGUILAR-MARCELINO, L., HUSSEIN, E.O.S., ALHIMAIDI, A.R. and SWELUM, A.A., 2023. Prevalence of gastrointestinal parasite in small ruminants of District Dir Upper Khyber Pakhtunkhwa Province of Pakistan. Brazilian Journal of Biology, vol. 83, e248978.

VERCRUYSSE, J. and CLAEREBOUT, E., 2001. Treatment vs non-treatment of helminth infections in cattle: defining the threshold. Veterinary Parasitology, vol. 98, no. 1-3, pp. 195-214. http://dx.doi.org/10.1016/S0304-4017(01)00431-9. PMid:11516586.

WALLER, P.J., 1994. The development of anthelmintic resistance in ruminant livestock. Acta Tropica, vol. 56, no. 2-3, pp. 233-243. http://dx.doi.org/10.1016/0001-706X(94)90065-5. PMid:8203305.

WALLER, P.J., 1999. International approaches to the concept of integrated control of nematode parasites of livestock. International Journal for Parasitology, vol. 29, no. 1, pp. 155164, discussion 183-184. http://dx.doi.org/10.1016/S00207519(98)00178-7. PMid:10048828. 